\title{
KOHERENCJA I SWOISTOŚĆ WARTOŚCI SEKTORÓW PUBLICZNEGO I PRYWATNEGO
}

\begin{abstract}
Badania nad funkcjonowaniem sektora publicznego i prywatnego skłaniają do wniosku, że mamy do czynienia ze stopniową konwergencją obu sektorów. Coraz częściej sektor publiczny odwołuje się do wartości rynkowych, z kolei sektor prywatny - do wartości właściwych sektorowi publicznemu. Dzieje się tak na skutek rosnących oczekiwań społecznych wobec organizacji biznesowych i publicznych. Od przedsiębiorstw społeczeństwo oczekuje prowadzenia działalności $\mathrm{z}$ poszanowaniem środowiska społecznego i naturalnego oraz partycypacji w realizacji funkcji socjalnych państwa. Z kolei od organizacji publicznych wymaga decentralizacji ośrodków decyzyjnych, inkluzji grup społecznych w sferę spraw publicznych czy wreszcie, kierowania się, w procesie tworzenia i dystrybucji dóbr publicznych, zasadami skuteczności i efektywności. Urzeczywistnienie tych dwóch zasad w praktyce, oznacza dbałość o terminową realizację zadań, uzyskiwanie najlepszych efektów z danych nakładów oraz optymalny dobór metod i środków służących osiągnięciu założonych celów ${ }^{2}$. Celem głównym artykułu jest określenie wybranych wartości wspólnych oraz różnicujących sektor publiczny i prywatny. Cele szczegółowe, podporządkowane realizacji tak sformułowanego celu głównego, to: Określenie istoty, rodzajów i znaczenia wartości. Charakterystyka głównych cech i funkcji petnionych przez sektor publiczny $i$ prywatny. Analiza porównawcza wartości organizacyjnych sektora publicznego $i$ prywatnego $w$ kontekście ewoluowania paradygmatów zarządzania. Artykuł ma charakter przeglądowy. Zastosowana metoda badawcza to analiza i krytyka piśmiennictwa.

Słowa kluczowe: wartości, nowe zarządzanie publiczne, zarządzanie publiczne, dobre rządy, odpowiedzialność społeczna przedsiębiorstw.
\end{abstract}

\section{WPROWADZENIE}

Lata 90. XX w. przyniosły wzrost zainteresowania wartościami w organizacjach. Wartości postrzegane są obecnie jako narzędzie wprowadzania zmian organizacyjnych, czy też kształtowania relacji z rożnymi grupami interesu. Coraz więcej podmiotów zaczyna identyfikować, wdrażać, chronić i kontrolować swoje kluczowe wartości. Celem głównym artykułu było określenie wartości wspólnych oraz różnicujących sektor publiczny i prywatny. W pierwszej jego części określona została istota, rodzaje oraz znaczenie wartości. Następnie scharakteryzowano główne cechy i funkcje pełnione przez sektor publiczny i prywatny oraz porównano wartości organizacyjne obu sektorów w kontekście ewoluowania paradygmatów zarządzania.

\footnotetext{
${ }^{1}$ Dr hab. Dorota Teneta-Skwiercz, Katedra Ekonomiki i Organizacji Przedsiębiorstwa, Uniwersytet Ekonomiczny we Wrocławiu, ul. Komandorska 118/120, 53-345 Wrocław, e-mail: alley77@poczta.onet.pl

${ }^{2}$ Por. art.44 ustawy o finansach publicznych z 27 sierpnia 2009 r. (Dz.U. nr 157, poz. 1240 ze zm.).
} 
Artykuł ma charakter przeglądowy. Zastosowana metoda badawcza to analiza i krytyka piśmiennictwa.

\section{POJECCIE, RODZAJE I ZNACZENIE WARTOŚCI WE WSPÓŁCZESNYCH ORGANIZACJACH}

Nie ma jednoznacznej definicji „wartości”. Termin ten ma niewątpliwie charakter interdyscyplinarny, przewija się $\mathrm{w}$ opracowaniach $\mathrm{z}$ zakresu takich dziedzin nauki jak filozofia, psychologia, socjologia, ekonomia czy nauki o zarządzaniu. Mnogość płaszczyzn postrzegania wartości zaowocowała też bogactwem hierarchii wartości. Na gruncie psychologii, na uwagę zasługuje ujęcie wartości Miltona Rokeacha. Ten uznany psycholog społeczny „wartość” definiuje jako „trwałe przekonanie, że dany sposób postępowania lub ostateczny cel życia jest jednostkowo i społecznie bardziej atrakcyjny niż inne sposoby zachowania się i inne cele życiowe"3. System wartości stanowi dla niego utrwaloną organizację przekonań dotyczących preferowanych sposobów postępowania oraz ostatecznych celów egzystencjalnych, uporządkowanych według względnej ważności. Najważniejszą kategorią wartości są dla badacza wartości ostateczne (autoteliczne). Osiąganie wartości ostatecznych możliwe jest dzięki wartościom instrumentalnym, do których Rokeach zaliczył wartości moralne, określające pożądane zachowania wobec innych ludzi (np. uczciwość, odpowiedzialność, zaufanie, solidarność, poszanowanie praw ludzkich, miłość, lojalność, wrażliwość) i kompetencyjne, pozwalające skutecznie realizować cele życiowe, zawodowe i społeczne (np. twórcza wyobraźnia, elastyczność, praca zespołowa, ambicja, odwaga itp.). W filozofii, szeroko rozpowszechnioną teorią wartości jest fenomenologiczna teoria wartości Maxa Schelera. Najwyżej w hierarchii Schelera znalazły sią wartości religijne (świętość), niżej wartości duchowe, tj. estetyczne (piękno-brzydota), porządku prawnego (słuszność-niesłuszność) i poznawcze (prawda-fałsz), wartości witalne (użyteczność i utylitaryzm) i wartości hedoniczne (przyjemność). Na gruncie ekonomii można wydzielić dwa sposoby ujmowania wartości. Pierwszy to wartość utylitarna odnosząca się nie tylko do korzyści, ale też do przyjemności, jakie czerpie użytkownik z aktualnie posiadanej rzeczy. Druga to wartość wymienna, która oznacza liczbę innych przedmiotów (zwykle pieniędzy), na jakie można wymienić posiadany towar ${ }^{4}$.

Wartości można analizować $\mathrm{w}$ aspekcie przedmiotowym, jako że treści i znaczenie im przypisywane, to inaczej sposób postrzegania i opisywania rzeczywistości, podmiotowym, gdyż przypisywane są jednostkom, zespołom lub organizacjom i wreszcie czynnościowym, ponieważ demonstrowane są poprzez działanie podmiotu wartości. W wymiarze jednostkowym wartości mogą być definiowane jako suma ludzkich preferencji i priorytetów. Dla M. Hendersona i D. Thomsona ${ }^{5}$ preferencje są tym, co chcielibyśmy mieć w naszym życiu, natomiast priorytety wskazują, jak ważna jest każda preferencja w stosunku do innej. Autorzy ci zwracają również uwagę na to, że wartości nie są tylko abstrakcyjnymi terminami. Muszą być doświadczane, gdyż tylko wówczas zyskują realne znaczenie. Zeger Van der Wal definiuje wartości jako pewne cechy, przymioty i standardy mające istotny wpływ na podejmowane działania, podkreśla przy

\footnotetext{
${ }^{3}$ M. Rokeach, The Nature of Human Values, New York 1973, s. 5.

${ }^{4}$ Dictionary of Economics Fourth edition, London 1987, s. 415.

5 Zob. M. Henderson, D. Thomson, Values at work: the invisible threads between people, performance and profit, Auckland 2003.
} 
tym, że nie można ich zobaczyć ani usłyszeć, możemy tylko obserwować sposób w jaki są manifestowane, tj. przyjmowane postawy, podejmowane decyzje i działanie ${ }^{6}$.

Analizując wartości na poziomie organizacyjnym możemy stwierdzić, iż stanowią one integralny element kultury organizacyjnej, uzewnętrzniają się w normach i artefaktach, Normy to niepisane zasady zachowania, reguły gry czy też nieformalne wytyczne dotyczące zachowań, natomiast artefakty, to widoczne, materialne i niematerialne aspekty organizacji, które ludzie słyszą, widzą lub odczuwają ${ }^{7}$.

Gdy większość członków organizacji nie tylko deklaruje przywiązanie, ale też faktycznie odwołuje się do kluczowych wartości promowanych przez liderów, mamy do czynienia z organizacją o utrwalonym, silnym systemie wartości. W praktyce, organizacje borykają się z brakiem spójności w obszarze wartości. Owe rozbieżności mogą pojawić się między wartościami indywidualnymi a wartościami organizacji jako całości, między wartościami deklarowanymi a tymi faktycznie przestrzeganymi. Dodatkowo, w sytuacji gdy wartości osobnicze mają różne podstawy światopoglądowe i religijne, uwidaczniają się różnice między wartościami cenionymi przez poszczególnych członków organizacji.

Wartości organizacyjne mogą zostać zakwalifikowane jako funkcjonalne lub instrumentalne. Wartości funkcjonalne dostarczają wskazówek do akceptowalnego zachowania w miejscu pracy i na ogół obejmują takie priorytety jak uczciwość, różnorodność, ciężka praca. W przeciwieństwie do nich wartości instrumentalne są wartościami strategicznymi, które „zapewniają uzasadnienie” dla działalności organizacji i łączą organizację ze środowiskiem i jej interesariuszami. Koncentrują się nie na pożądanych sposobach zachowania a na końcowych pożądanych rezultatach, takich jak prestiż organizacyjny lub kondycja finansowa ${ }^{8}$. S.L. Dolan i Y. Altman, biorąc pod uwagę charakter wartości, wskazują na istnienie trzech wiązek wartości w organizacjach ${ }^{9}$ :

- wartości ekonomiczno-pragmatycznych, obejmujących m.in. skuteczność i efektywność; wartości te zapewniają przetrwanie organizacji w konkurencyjnym środowisku,

- wartości etyczno-społecznych, wynikających z przekonań i obyczajów dotyczących tego jak ludzie powinni zachowywać się w miejscach publicznych, w pracy; przykładem tego rodzaju wartości jest uczciwość, rzetelność, szacunek i lojalność,

- wartości emocjonalno-rozwojowych, niezbędnych do tworzenia impulsów do działania; są to wartości związane z wewnętrzną motywacją, takie jak: optymizm, pasja, postrzegane wolności.

Wartości w sposób zasadniczy rzutują na jakość praktyk zarządzania w organizacjach ${ }^{10}$. Stanowią też najbardziej skuteczną barierę dla zachowań

\footnotetext{
${ }^{6}$ Z. Van der Wal, G. de Graaf, K. Lasthuizen, What's Valued Most? Similarities and Differences between the Organizational Values of the Public and Private Sector, Public Administration 2008, 86(2), p. 468.

${ }^{7}$ M. Armstrong, Zarządzanie zasobami ludzkimi. Warszawa 2011, s. 343-344.

${ }^{8}$ L. E. Paarlberg, J. L. Perry, Values Management Aligning Employee Values and Organization Goals 2007, "The American Review of Public Administration" 2007, 37 (4), p. 389.

${ }^{9}$ S. Dolan, Y. Altman, Managing by Values: The Leadership Spirituality Connection, People \& Strategy" 2012, 35 (4), p. 21.

10 B. Gerhart, "Cross-cultural Management Research: Assumptions, Evidence, and Suggested Directions" 2008, International Journal of Cross-Cultural Management 8 (3), p. 259-274.
} 
oportunistycznych. Dzieje się tak, gdyż wspólne wartości pozwalają jednostkom działać dla dobra ogółu w oczekiwaniu na akceptację społeczną, dobre traktowanie w geście wzajemności lub ze strachu przed karą społeczną ${ }^{11}$. W organizacjach komercyjnych wartości mogą przyczynić się do: zwiększenia zysków dla interesariuszy, budowania lojalności do marki, podniesienia atrakcyjności firmy jako miejsca pracy. W organizacjach publicznych - sprzyjają dostarczaniu wysokiej jakości usług, retencji utalentowanych pracowników, tworzeniu podstaw zrównoważonego rozwoju społeczeństwa.

\section{ANALIZA PORÓWNAWCZA CECH I FUNKCJI SEKTORA PUBLICZNEGO I PRYWATNEGO}

Zdaniem J. Stiglitza, granica między sektorem prywatnym i publicznym w gospodarce rynkowej jest dość płynna ${ }^{12}$. Niewątpliwie, można mówić o współzależności obu sektorów. Z jednej strony sektor prywatny korzysta $\mathrm{z}$ usług świadczonych przez państwo, jego działalność, możliwości rozwojowe są determinowane przez porządek prawny tworzony przez organy państwowe. $Z$ drugiej strony państwo zasilane jest przez środki pochodzące $z$ gospodarki prywatnej, co prowadzi do konstatacji, że sektor prywatny jest warunkiem istnienia państwa.

Sektor publiczny stanowi element nierynkowego otoczenia przedsiębiorstwa. Tworzą go podmioty państwowe i samorządowe, organizacyjnie podległe organom władzy publicznej. Trzy główne funkcje przypisywane temu sektorowi to funkcja alokacyjna, stabilizacyjna i redystrybucyjna. Funkcja alokacyjna sprowadza się do oddziaływania, poprzez dochody i wydatki publiczne, na rozmieszczenie różnego rodzaju zasobów w gospodarce. Chodzi o alokację zarówno czynników produkcyjnych (surowców, materiałów, maszyn, pracy), jak i wytworzonych dóbr. Funkcja redystrybucyjna (rozdzielcza) skupia się na działaniach zmierzających do niwelowania nadmiernych, nie akceptowanych społecznie, różnic dochodowych i majątkowych. $Z$ kolei funkcja stabilizacyjna, polega na podejmowaniu przez państwo działań służących przeciwdziałaniu załamaniom koniunktury, ograniczeniu inflacji i bezrobocia, utrzymaniu w dłuższym okresie czasu wysokiego tempa wzrostu gospodarczego. Sektor ten zorientowany jest na zaspokajanie tych potrzeb społecznych, których sektor prywatny nie może bądź nie chce, z uwagi na brak opłacalności, zaspokoić. Do zadań tego sektora, których nie może wykonywać sektor prywatny, należą w szczególności: zadania obronnowojskowe, obejmujące ochronę suwerenności i bezpieczeństwa państwa, zadania związane $\mathrm{z}$ zapewnieniem ładu prawno-instytucjonalnego oraz ochrona własności i wolności jednostek ${ }^{13}$.

Sektor prywatny definiowany jest w statystyce publicznej jako ogół podmiotów gospodarki narodowej grupujący własność prywatną krajową (osób fizycznych i pozostałych jednostek prywatnych), własność zagraniczną (osób zagranicznych) oraz „własność mieszaną" z przewagą kapitału podmiotów sektora prywatnego ${ }^{14}$. Główną jego

\footnotetext{
${ }^{11}$ V.C. Petersen, Beyond rules in society and business, Northampton 2002.

12 J. Stiglitz, Ekonomia sektora publicznego, Warszawa 2004, s. 15.

${ }^{13}$ J. Kleer (red.), Sektor publiczny w Polsce i na świecie między upadkiem i rozkwitem, Warszawa 2005 , s. 274-277.

${ }^{14}$ http://stat.gov.pl/ (dostęp: 29.04.2016 r.).
} 
funkcją jest wytwarzanie dóbr i świadczenie usług, tworzenie miejsc pracy, innowacyjność i zapewnienie rozwoju gospodarczego.

Dobra publiczne, w przeciwieństwie do dóbr prywatnych, finansowane są ze środków publicznych pochodzących danin publicznych, nie ulegają wyczerpaniu i nie zmniejszają się w miarę wzrostu liczby korzystających z nich podmiotów. Dostępu do nich nie można też nikomu ograniczyć. O dobra te podmioty na ogół nie konkurują ze sobą ${ }^{15}$.

Praca w sektorze publicznym nie tylko wymaga odpowiedniego przygotowania merytorycznego ale też narzuca pewne ograniczenia w zakresie prowadzenia przez urzędników działalności politycznej ${ }^{16}$. Od pracownika publicznego wymaga się, aby był uprzejmy i życzliwy w kontaktach z obywatelami, zwierzchnikami, podwładnymi oraz współpracownikami, zachowywał się z godnością w miejscu pracy i poza nim oraz stałe podnosił umiejętności i kwalifikacje zawodowe ${ }^{17}$. Tego rodzaju zastrzeżeń nie znajdziemy w regulacjach odnoszących się do sektora prywatnego.

J. Boć, porównując cechy administracja prywatnej i publicznej, wskazuje na istotne różnice między nimi, dotyczące chociażby charakteru realizowanych przez nie celów, zadań, motywacji do działania oraz umocowania prawnego. I tak, stwierdza, że ${ }^{18}$ :

- cele i zadania administracji prywatnej są wąskie, a administracji publicznej szerokie,

- cele administracji prywatnej wyznacza rynek, cele administracji publicznej państwo,

- zadania administracji prywatnej są wewnętrzne, podczas gdy publicznej zewnętrzne,

- główną motywacją działania administracji prywatnej jest ochrona interesu prywatnego, a główną motywacją administracji publicznej jest ochrona interesu publicznego,

- działalność administracji prywatnej opiera się na prawie cywilnym i handlowym, a administracji publicznej - na prawie administracyjnym, przez co może ona stosować środki władcze,

- administracja prywatna prowadzona jest w imieniu właściciela, a administracja publiczna - w imieniu państwa,

- związana $\mathrm{z}$ właścicielem i przedsiębiorstwem administracja prywatna ma charakter przejściowy, podczas gdy administracja publiczna jest trwała.

Organizacje publiczne są w większym stopniu niż prywatne poddane kontroli ze strony administracji państwowej. Co więcej, efekty ich działania znacznie trudniej skwantyfikować niż efekty działań organizacji prywatnych. Różnice między tymi sektorami ujawniają się też w obszarze kluczowych interesariuszy. Dla sektora prywatnego będą to właściciele, menedżerowie, pracownicy, klienci, dostawcy i konkurencja. Dla organizacji publicznych - obywatele, podatnicy, beneficjenci usług publicznych, organy władzy, urzędnicy i organizacje trzeciego sektora. Organizacje publiczne nie są nastawione na zysk, umożliwiają obywatelom korzystanie z należnych

${ }^{15}$ Ł. Popławski, M. Głuch, Efektywność finansowania zadań sektora publicznego, „Dylematy” 2013, nr 3, s. 67.

${ }^{16}$ M. Kulesza, M. Niziołek, Etyka stużby publicznej, Warszawa 2010, s. 75.

${ }^{17}$ Art. 24 pkt 2 ustawy z dnia 21 listopada 2008 r. o pracownikach samorządowych (Dz.U. nr 223, poz. 1458 ze zm.).

${ }^{18}$ J. Boć, Administracja publiczna, Wrocław 2004, s. 67. 
praw, informują, zapewniają stabilność i usankcjonowanie prawne. Z kolei sektor prywatny skoncentrowany jest na zyskach. Przypisuje mu się zazwyczaj takie atrybuty jak: inwencja, produktywność, wysoka motywacja i szybkość działania.

\section{EWOLUCJA KLUCZOWYCH WARTOŚCI W BADANYCH SEKTORACH}

\subsection{Zmiana paradygmatu zarządzania organizacjami publicznymi}

Od połowy lat 80. XX wieku w całej Europie Zachodniej zaczęły się ogromne zmiany w zakresie zarządzania administracją publiczną. Weberowski model biurokracji, cechujący się koncentracją na procedurach, a nie na wynikach ich stosowania, ścisłą kontrolą, odrębnością organizacji publicznej od otoczenia, naukowym doborem kadr, hierarchicznością i literalnym stosowaniem prawa, stopniowo ustępował miejsca modelowi zakładającemu funkcjonowanie sektora publicznego w oparciu o reguły właściwe sektorowi prywatnemu. W praktyce oznaczało to wykorzystywanie mechanizmów rynkowych oraz nacisk na odpowiedzialność za uzyskane wyniki i jakość świadczonych usług. Powodów owych zmian można upatrywać w trzech nasilających się tendencjach: wzroście znaczenia rynku usług i zarazem konkurencji między podmiotami na nim działającymi, wzroście świadomości politycznej i praw obywatelskich na skutek rozwoju środków masowego przekazu oraz wzroście udziału obywateli w sprawowaniu władzy publicznej poprzez tworzenie organizacji społecznych i stowarzyszeń ${ }^{19}$. W odpowiedzi na powyższe wyzwania, wyłoniły się nowe modele zarządzania instytucjami publicznymi, koncentrujące się na odmiennych od dotychczasowych, wartościach. Wzmiankowane modele to Nowe zarządzanie publiczne (ang. New Public Management - NPM), Partycypacyjne zarządzanie publiczne (ang. Public governance NG) i Dobre rządzenie (ang. Good governance - GG). Ewolucję modeli zarzadzania w sektorze publicznym prezentuje rys. 1 .

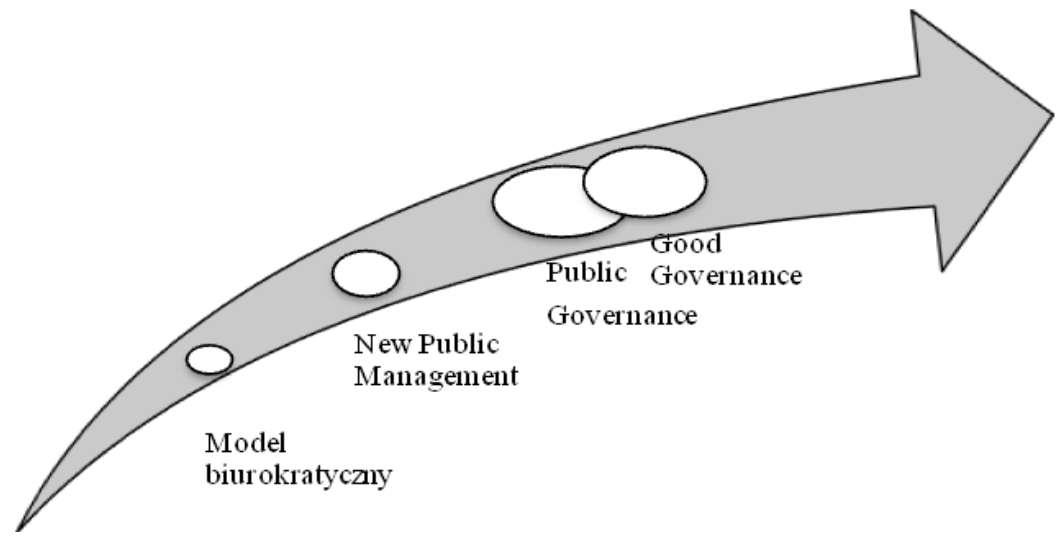

Rys. 1. Ewolucja modeli zarządzania publicznego

Źródło: opracowanie własne.

19 M. Ochnio, Nowe zarzadzanie publiczne, podstawowe cechy modelu. Jego zastosowanie w Polsce, ,Working Paper” 2012, nr 1, s. 5. 
Według A. Zalewskiego głównymi elementami koncepcji NPM, określanej mianem menedżeryzmu publicznego, rynkowej administracji publicznej, czy też zarządzaniem publicznym na zasadach rynkowych, są ${ }^{20}$ : honorowanie zasady racjonalnego gospodarowania, która prowadzi do większej dyscypliny i oszczędności w procesach dysponowania powierzonymi zasobami, zarządzanie przez menedżera publicznego (public manager), profesjonalizm urzędników, doskonalenie kompetencji, precyzyjność w określaniu standardów i tworzeniu mierników oceny działalności, przyjazność dla obywatela, humanizm organizacyjny, poprawa skuteczności procesów budżetowania, monitorowania i kontroli oraz ocena uzyskanych wyników. Z kolei J. Supernat wskazuje na takie założenia NPM, jak: orientacja w pierwszej kolejności na wyniki, a dopiero później na wejścia i procesy działania, wprowadzanie mechanizmów rynkowej konkurencji (np. prywatyzacja, outsourcing), orientacja na konsumenta, sieciowy i współzależny $\mathrm{z}$ sektorem prywatnym i społecznym układ świadczenia usług publicznych, deregulacja oznaczająca większą swobodę w korzystaniu $\mathrm{z}$ zasobów ${ }^{21}$. Model NPM kładzie nacisk na przedsiębiorczość pracowników, ich upodmiotowienie, wyzwalanie oddolnej inicjatywy i kreatywności.

Kolejnym podejściem do zarządzania w organizacjach publicznych, była koncepcja Public governance. Podejście to, w szerszym zakresie niż NPM, uwzględnia interakcje organizacji publicznej z elementami otoczenia politycznego, społecznego i gospodarczego oraz postuluje zarządzanie relacjami z kluczowymi grupami interesu, tj. mieszkańcami, obywatelami, przedsiębiorcami i organizacjami pozarządowymi. Praktycznym uszczegółowieniem podejścia Public governance była koncepcja Good governance ${ }^{22}$, która oprócz odpowiedzialności, praworządności, słuszności i inkluzywności, podkreśla znaczenia takich wartości w organizacjach publicznych, jak $^{23}$ :

- otwartość, polegająca na maksymalnej transparentności instytucji administracyjnych dla obywateli i opinii publicznej,

- partycypacja, oznaczająca szeroki udział społeczeństwa w pracach administracyjnych, na wszystkich poziomach władz publicznych, a także na wszystkich głównych etapach realizacji polityk publicznych ( $\mathrm{tj}$. w trakcie programowania, implementacji i monitoringu),

- rozliczalność, sprowadzająca się do precyzyjnego określania zakresu odpowiedzialności poszczególnych instytucji, a zwłaszcza zapewniania podziału władzy między władzę ustawodawczą i wykonawczą,

- efektywność, oznaczająca skuteczne, sprawne (tj. bez niepotrzebnej zwłoki) realizowanie celów polityk publicznych.

Analiza zaprezentowanych modeli zarządzania publicznego wyraźnie wskazuje na stopniowe ewoluowanie wartości w sektorze publicznym. W modelu biurokratycznym do kluczowych wartości należała centralizacja, legalizm, depersonalizacja rozumiana jako

\footnotetext{
${ }^{20}$ Por. A. Zalewski (red.), Nowe zarzadzanie publiczne $w$ polskim samorzadzie terytorialnym, Warszawa 2005, s. 27.

${ }^{21}$ J. Supernat, Administracja publiczna w świetle koncepcji New Public Management, Administracja Publiczna. Studia Krajowe i Międzynarodowe, 28-46, Zeszyty Naukowe Wyższej Szkoły Administracji Publicznej w Białymstoku 2003, nr 2.

22 J. Hausner, Zarządzanie publiczne, Warszawa 2008, s. 424.

${ }^{23}$ Koncepcja good governance - refleksje do dyskusji, Ministerstwo Rozwoju Regionalnego, Departament Koordynacji Polityki Strukturalnej, Warszawa 2008, s. 8.
} 
pozbawienie stosunków pomiędzy urzędnikami i pomiędzy urzędnikami a petentami elementów osobistych i emocjonalnych, profesjonalizm oparty na kryteriach formalnych i efektywność rozumiana jako przystosowanie organizacji do działań celowych. Nowe modele zarządzania publicznego podkreślają znaczenie decentralizacji, rozumianej jako przekazywanie zadań niższym szczeblom w hierarchii jak też podmiotom sektora prywatnego i społecznego, odpowiedzialności za rezultaty, jakość usług i etykę działania funkcjonariuszy publicznych, orientacji na klienta, zakładająca dostosowywanie usług do potrzeb i oczekiwań klienta postrzeganego jako konsument usług publicznych, profesjonalizmu opartego na umiejętnościach menedżerskich oraz efektywności rozumianej jako zdolność do bieżącego przystosowywania się do zmian w otoczeniu i oszczędnego wykorzystywania zasobów.

\subsection{Redefinicja celów i wartości przedsiębiorstw w kontekście upowszechniania koncepcji społecznej odpowiedzialności biznesu}

Analiza rożnych teorii przedsiębiorstwa wskazuje na stopniowe odchodzenie organizacji komercyjnych od realizacji celów właściciela na rzecz uwzględniania oczekiwań szerokiego grona grup interesu. I tak, według teorii neoklasycznej, podstawowym celem przedsiębiorstwa jest maksymalizacja zysku, a ponieważ to właściciel zaopatruje przedsiębiorstwo $\mathrm{w}$ niezbędne zasoby, on też jest wyłącznym dysponentem wypracowanego zysku. Tak więc przedsiębiorstwo, zgodnie $\mathrm{z}$ tym podejściem, służy wyłącznie właścicielowi. Z kolei teoria interesariuszy, która stała się podwaliną koncepcji społecznej odpowiedzialności biznesu (ang. Corporate Social Resposibility - CSR), podkreśla, że przedsiębiorstwo uwzględniać potrzeby i oczekiwania szerokiego grona interesariuszy, zarówno wewnętrznych (właścicieli, pracowników, menedżerów) jak i zewnętrznych (dostawców, partnerów biznesowych, konkurencji itd.).

Punktem przełomowym dla rozwoju koncepcji CSR w Europie, było opublikowanie w 2001 r. tzw. Zielonej Księgi, w której zdefiniowane zostały kryteria działań społecznie odpowiedzialnych. Do kryteriów tych zaliczono: dobrowolność, wykraczanie poza ustanowione prawnie zobowiązania, zrównoważony i długoterminowy charakter podejmowanych inicjatyw, partnerstwo w relacjach $\mathrm{z}$ interesariuszami, oraz przejrzystość działania $^{24}$. CSR jest koncepcją integrującą ekonomiczne, prawne, społeczne, etyczne i środowiskowe aspekty funkcjonowania sektora biznesu. Przedsiębiorstwa społecznie odpowiedzialne wychodzą z założenia, że osiąganie zysków nie wyklucza troski o szeroko pojęte środowisko społeczne i przyrodnicze, dlatego aktywne angażują się w doskonalenie środowiska pracy, rozwiązywanie problemów społeczności lokalnych, wspieranie organizacji pozarządowych i ochronę środowiska naturalnego.

Niewątpliwie CSR promuje takie tradycyjne wartości sektora publicznego, takich jak zrównoważony rozwój, odpowiedzialność, solidarność i sprawiedliwość społeczną, związaną z mechanizmami dystrybucji bogactwa i przywilejów socjalnych.

\footnotetext{
${ }^{24}$ Por. D. Teneta-Skwiercz, Uwarunkowania realizacji koncepcji spolecznej odpowiedzialności biznesu w przedsiębiorstwach polskich na tle doświadczeń Wielkiej Brytanii i Niemiec, Wrocław 2013.
} 


\section{KLUCZOWE WARTOŚCI SEKTORA PUBLICZNEGO I PRYWATNEGO - WYNIKI BADAŃ}

W literaturze przedmiotu można odnaleźć liczne badania, których przedmiotem są wartości dominujące czy to w sektorze publicznym czy w prywatnym. Istnieje jednak wyraźny deficyt opracowań o charakterze porównawczym, dlatego tak cenne wydają się badania przeprowadzone przez Zegera Van der Wal. Badacz, poszukując wartości specyficznych dla sektora publicznego i prywatnego oraz wspólnych obu sektorom, przeprowadził w 2008 r. w Holandii badania na próbie 231 kierowników organizacji publicznych i 151 przedstawicieli kadry zarządzającej średnich i dużych przedsiębiorstw. Dzięki analizie obszernej literatury dotyczącej organizacji publicznych i etyki biznesu, zidentyfikowano ponad 500 różnych wartości organizacyjnych. Ostatecznie wyłoniono zestaw 20 wartości (tab. 1), w którym znalazły się wartości tradycyjne przypisane sektorowi publicznemu (bezstronność, legalność, sprawiedliwość społeczna) oraz sektorowi prywatnemu (innowacyjność, rentowność i samorealizacja).

Tabela 1. Interpretacja 20 kluczowych wartości objętych badaniem

\begin{tabular}{|c|c|}
\hline 20 kluczowych wartości & Definicje \\
\hline $\begin{array}{l}\text { Odpowiedzialność/Rozliczalność } \\
\text { (Accountability) }\end{array}$ & $\begin{array}{l}\text { chętne uzasadnianie i wyjaśnianie podejmowanych działań } \\
\text { istotnym interesariuszom }\end{array}$ \\
\hline hość (Collegiality) & $\begin{array}{l}\text { działanie w sposób lojalny i demonstrowanie solidarności ze } \\
\text { współpracownikami }\end{array}$ \\
\hline Poświęcenie (Dedication) & sumienność, entuzjazm i wytrwałość \\
\hline Skuteczność (Effect & działanie w celu osiągnięcia pożądanych \\
\hline Efekty & $\begin{array}{l}\text { działanie w celu osiągnięcia rezultatów przy użyciu } \\
\text { minimalnych środków }\end{array}$ \\
\hline Profesjo & $\begin{array}{l}\text { działanie w sposób kompetentny, w oparciu o posiadane } \\
\text { umiejętności i wiedzę }\end{array}$ \\
\hline Uczciwość (Honesty) & działanie zgodnie z prawdą i obietnicami \\
\hline Bezs & $\begin{array}{l}\text { działanie bez uprzedzeń lub stronniczości } \\
\text { konkretnych grup interesów }\end{array}$ \\
\hline $\begin{array}{l}\text { Nieprze } \\
\text { (Incorru }\end{array}$ & $\begin{array}{l}\text { działanie bez uprzedzeń i stronniczości wobec interesów } \\
\text { prywatnych }\end{array}$ \\
\hline Innowacyjność (Innovativeness) & $\begin{array}{l}\text { przejawianie inicjatywy i kreatywności (kreowanie lub } \\
\text { wprowadzenia nowych metod działania lub produktów) }\end{array}$ \\
\hline Legalność (Lawfulness) & $\begin{array}{l}\text { działanie zgodnie } \mathrm{z} \text { obowiązującymi przepisami prawa } \\
\text { i regułami }\end{array}$ \\
\hline Posłuszeństwo (Obedience) & $\begin{array}{l}\text { działanie zgodnie z instrukcjami i polityką (przełożonych } \\
\text { i organizacji) }\end{array}$ \\
\hline ść (Profitability) & działanie w celu osiągnięcia zysku (finansowego lub innego) \\
\hline Niezawodność (Reliability) & $\begin{array}{l}\text { działanie w godny zaufania i konsekwentny sposób wobec } \\
\text { interesariuszy }\end{array}$ \\
\hline Reagowanie (Responsiveness) & działanie zgodnie z preferencjami obywateli i klientów \\
\hline $\begin{array}{l}\text { Samorealizacja } \\
\text { fulfillment) }\end{array}$ & $\begin{array}{l}\text { działanie w celu stymulowania } \text { rozwoju i dobrego } \\
\text { samopoczucia pracowników }\end{array}$ \\
\hline
\end{tabular}




\begin{tabular}{|l|l|}
\hline Użyteczność (Serviceability) & $\begin{array}{l}\text { bycie pomocnym, oferowanie wysokiej klasy produktów } \\
\text { i usług na rzecz obywateli i klientów }\end{array}$ \\
\hline $\begin{array}{l}\text { Sprawiedliwość } \\
\text { (Social justice) }\end{array}$ & $\begin{array}{l}\text { podejmowanie zobowiązań na rzecz sprawiedliwego } \\
\text { społeczeństwa }\end{array}$ \\
\hline Trwałość (Sustainability) & zaangażowanie na rzecz przyrody i środowiska społecznego \\
\hline Przejrzystość (Transparency) & działanie w sposób jawny, poddawanie się kontroli \\
\hline
\end{tabular}

Źródło: Z. Van Der Wal, op. cit., s. 470.

Za wartości wspólne obu sektorom uznano: odpowiedzialność, profesjonalizm, uczciwość, odpowiedzialność społeczną i przejrzystość.

Badacze byli świadomi faktu, iż odpowiedzi na pytania kwestionariusza miały charakter deklaratywny i być może prezentowały obraz idealistyczny, znacznie odbiegający od faktycznych praktyk organizacyjnych. Tym niemniej, ponieważ przedmiotem badań była wyłącznie percepcja owych wartości, to zastosowaną metodę badawczą uznali za właściwą.

Respondenci zostali poproszeni o uszeregowanie według kryterium ważności, pięciu wartości, które wpływają na podejmowanie decyzji w ich organizacji. Wartości oceniane były w skali 5 -stopniowej, gdzie 5 oznaczało najważniejszą wartość, 1 - najmniej ważną. Abstrahowano od indywidualnych wartości moralnych menedżerów, chodziło o wartości na poziomie organizacji. Badania wykazały, że wartością, która odgrywa najważniejszą rolę $\mathrm{w}$ procesie podejmowania decyzji $\mathrm{w}$ organizacjach publicznych jest odpowiedzialność. Drugą wysoko cenioną wartością okazała się legalność. Na trzecim, czwartym i piątym miejscu znalazły się odpowiednio: profesjonalizm, nieprzekupność i niezawodność. Pięć najmniej cenionych wartości to: zyskowność, samorealizacja, posłuszeństwo, sprawiedliwość społeczna i trwałość (patrz rys. 2).

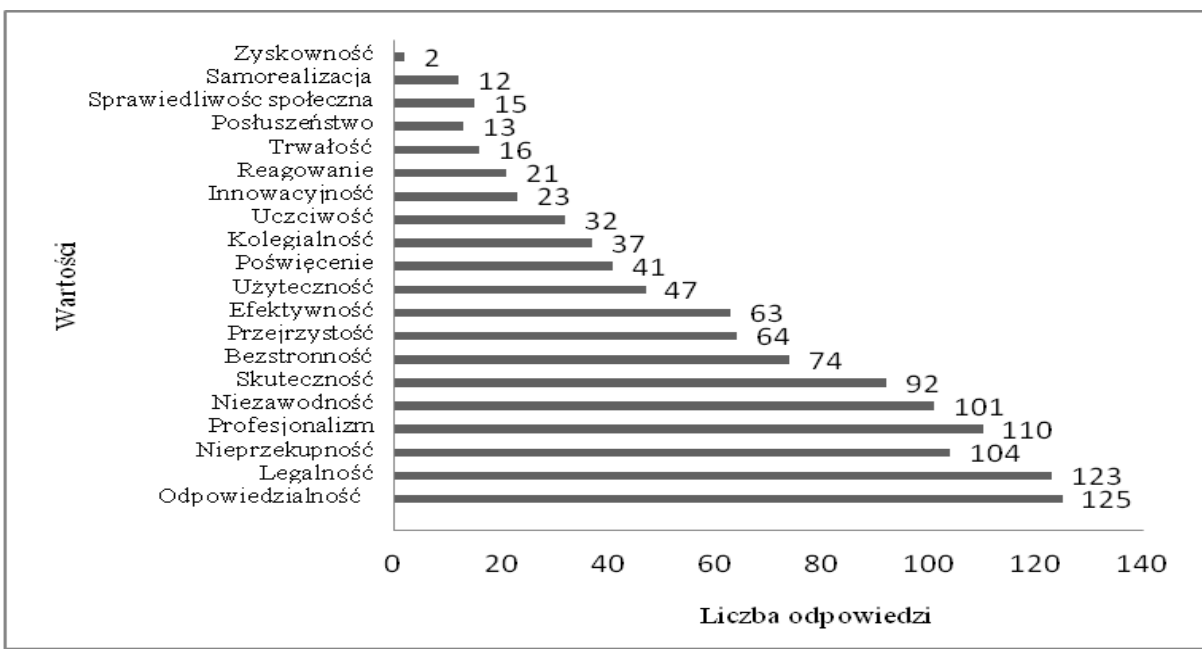

Rys. 2. Kluczowe wartości sektora publicznego $(\mathrm{n}=231)$

Źródło: opracowanie własne na podst. Zeger Van der Wal, op. cit., s. 473. 
W grupie organizacji prywatnych pięć najwyższej cenionych wartości to zyskowność, niezawodność, odpowiedzialność, profesjonalizm i skuteczność. Z kolei za mniej istotne uznano: sprawiedliwość społeczną, samorealizację, posłuszeństwo i reagowanie (rys. 3). Badania wykazały, że pięć najwyżej cenionych, wspólnych wartości obu sektorom to: odpowiedzialność, profesjonalizm, niezawodność, skuteczność i efektywność.

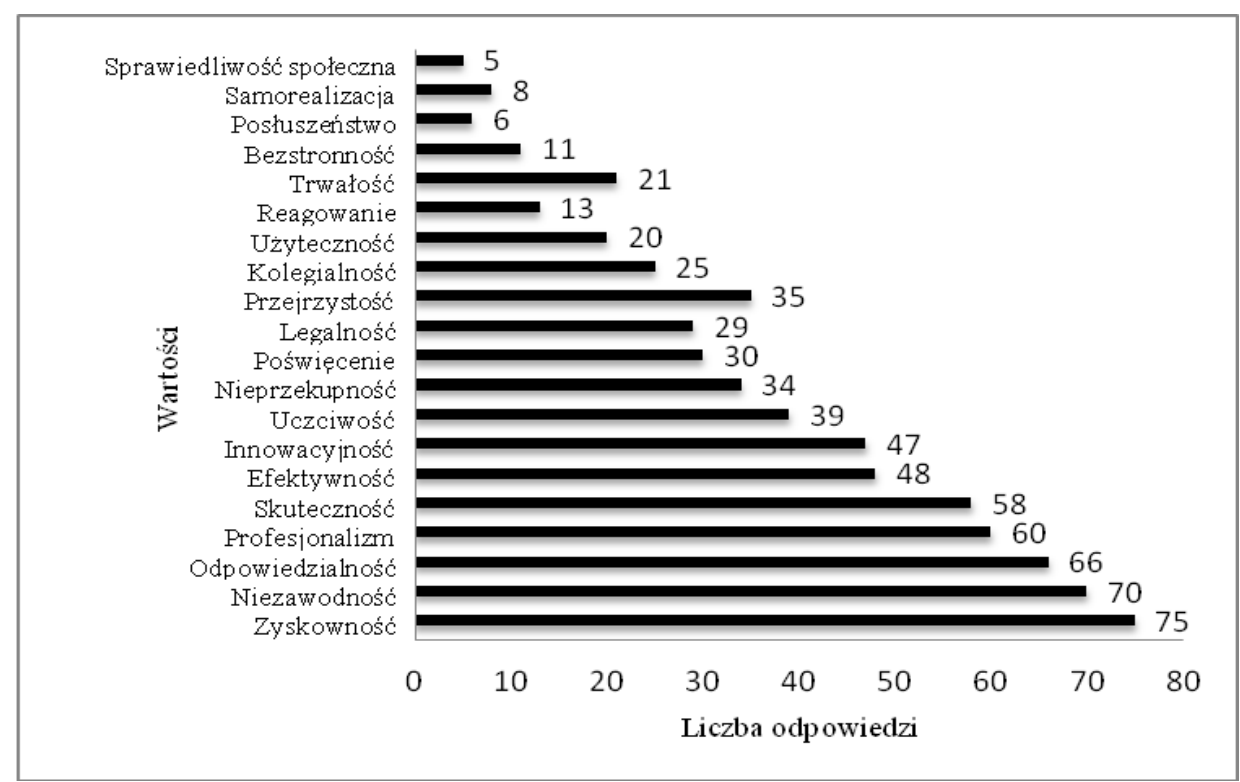

Rys. 3. Kluczowe wartości sektora biznesu ( $\mathrm{n}=151)$

Źródło: opracowanie własne na podst. Z. Van der Wal, op. cit., s. 473.

Analiza wyników badań prowadzi do kilku zaskakujących wniosków. I tak, o ile zrozumiała jest niska pozycja w hierarchii wartości organizacji publicznych zyskowności, wynika bowiem bezpośrednio $\mathrm{z}$ charakteru $\mathrm{i}$ roli tego rodzaju organizacji w społeczeństwie, o tyle może dziwić niska pozycja sprawiedliwości społecznej. Realizacja tej wartości wiąże się z kwestią bezpieczeństwa socjalnego, zaspokajania podstawowych potrzeb bytowych, podejmowania działań na rzecz ograniczenia ubóstwa, wykluczenia społecznego i wspomagania grup najsłabszych ekonomicznie a więc realizacją zadań immanentnie związanych z sektorem publicznym. Na uwagę zasługuje też wysokie miejsce wśród wartości cenionych przez sektor publiczny nieprzekupności. Rodzi się w tym miejscu pytanie, czy podobnie wysoką pozycję zajmuje ta wartość w polskich organizacjach? Niewątpliwie, udzielenie wiarygodnej odpowiedzi na tak zadane pytanie wymagałoby przeprowadzenia stosownych badań empirycznych tym niemniej, interpretacja opublikowanego przez Transparency International w styczniu 2016 r. „Indeksu Percepcji Korupcji 2015 roku”, mierzącego postrzeganie korupcji 
w sektorze publicznym pozwala domniemywać, że polskie organizacje publiczne nie cenią $\mathrm{w}$ równym stopniu co holenderskie nieprzekupności ${ }^{25}$.

Nieoczekiwanie nisko $\mathrm{w}$ hierarchii wartości organizacji prywatnych znalazła się, przypisywana temu sektorowi przez badacza samorealizacja, co w powiązaniu z niską pozycją takich wartości jak trwałość i sprawiedliwość społeczna, może świadczyć o słabym zakorzenieniu wśród badanych podmiotów idei społecznej odpowiedzialności biznesu. Dla obu sektorów wysoką wartość przedstawia odpowiedzialność, należy jednak zauważyć, iż w prezentowanych badaniach utożsamiana jest raczej z rozliczalnością, a nie stanem powinności, występującym w obrębie pewnej rzeczywistości.

\section{ZAKOŃCZENIE}

Badania nad funkcjonowaniem sektora publicznego i prywatnego skłaniają do wniosku, że mamy do czynienia ze stopniową konwergencją obu sektorów. Sprzyja temu upowszechnianie takich koncepcji zarządzania jak Społeczna odpowiedzialność biznesu, Nowe zarządzanie publiczne, Współdecydowanie publiczne. W efekcie coraz częściej sektor publiczny odwołuje się do wartości rynkowych, z kolei sektor prywatny - do wartości właściwych sektorowi publicznemu. W międzysektorowym przenikaniu cech, ról, funkcji, stosowanych metod i narzędzi zarządzania, można upatrywać zarówno korzyści jak i zagrożeń. $Z$ jednej strony, wspomniana konwergencja stwarza szanse wzrostu efektywności wykorzystania posiadanych przez nie zasobów, doskonalenia zarządzania relacjami z interesariuszami oraz poprawy stany środowiska naturalnego, co ma niebagatelne znaczenie dla jakości życia obecnego i przyszłych pokoleń. Z drugiej, rodzi obawy związane $\mathrm{z}$ generowaniem dodatkowych kosztów, deregulacją, faktyczną możliwością godzenia celów ekonomicznych ze społecznymi oraz nadmiernym przywiązaniem do tradycyjnie przypisanych ról $i$ odpowiedzialności. Efektem powyższych zagrożeń może być pozorowany, zorientowany wyłącznie na poprawę wizerunku, charakter podejmowanych przez oba sektory działań.

\section{LITERATURA}

[1] Armstrong M., Zarzadzanie zasobami ludzkimi, Oficyna a Wolters Kluwer Business, Warszawa 2011.

[2] Boć J., Administracja publiczna, Kolonia Limited, Wrocław 2004.

[3] Corruption Perceptions Index 2015, http://www.transparency.org (dostęp: 20.03.2016 r).

[4] Dictionary of Economics Fourth edition, Penguin Books, London 1987.

[5] Dolan S., Altman Y., Managing by Values: The Leadership Spirituality Connection, "People \& Strategy" 2012, 35 (4), p. 21

\footnotetext{
${ }^{25} \mathrm{~W}$ badaniu Transparency International eksperci z całego świata, oceniali korupcję w skali od 0 (bardzo skorumpowane organizacje) do 100 (bardzo uczciwe organizacje - „,very clean”). Wśród 168 badanych krajów aż dwie trzecie krajów uzyskało wynik poniżej 50 punktów. Za najmniej skorumpowane zostały uznane organizacje publiczne w takich krajach jak: Dania, Finlandia, Szwecja, Nowa Zelandia i Holandia. Polska uplasowała się na 30. miejscu, wyprzedzając takie kraje naszego regionu jak: Litwa, Słowenia, Czechy i Łotwa; źródło: Corruption Perceptions Index 2015, http://www.transparency.org (dostęp: 20.03.2016 r.).
} 
[6] Gerhart B., Cross-cultural Management Research: Assumptions, Evidence, and Suggested Directions, "International Journal of Cross-Cultural Management" 2008, 8 (3), p. 259-274.

[7] Hausner J., Zarzadzanie publiczne, Wydawnictwo Naukowe Scholar, Warszawa 2008.

[8] Henderson M., Thomson D., Values at work: the invisible threads between people, performance and profit, Harper Collins Publishers, Auckland 2003.

[9] http://stat.gov.pl/ (dostęp: 29.04.2016 r.).

[10]Kleer J. (red.), Sektor publiczny $w$ Polsce $i$ na świecie między upadkiem i rozkwitem, Wydawnictwo CeDeWu, Warszawa 2005.

[11] Koncepcja good governance - refleksje do dyskusji, 2008, Ministerstwo Rozwoju Regionalnego, Departament Koordynacji Polityki Strukturalnej, Warszawa.

[12]Kulesza M., Niziołek M., Etyka służby publicznej, Wolters Kluwer Polska, Warszawa 2010.

[13] Ochnio M., Nowe zarzadzanie publiczne, podstawowe cechy modelu. Jego zastosowanie w Polsce, ,Working Paper” 2012, 1, s. 5.

[14]Paarlberg Laurie E., Perry J., Values Management Aligning Employee Values and Organization Goals, "The American Review of Public Administration" 2007, 37 (4), p. 389.

[15]Petersen V.C., Beyond rules in society and business, Northampton 2002.

[16] Popławski Ł., Głuch M., Efektywność finansowania zadań sektora publicznego, „Dylematy” 2014, 3, s. 67.

[17]Rokeach M., The Nature of Human Values, Free Press, New York 1973.

[18] Stiglitz J., Ekonomia sektora publicznego, PWN, Warszawa 2004.

[19]Supernat J., Administracja publiczna $w$ świetle koncepcji New Public Management, Administracja Publiczna. Studia Krajowe i Międzynarodowe, Zeszyty Naukowe Wyższej Szkoły Administracji Publicznej w Białymstoku, 2003, nr 2, s. 28-43.

[20]Teneta-Skwiercz D., Uwarunkowania realizacji koncepcji społecznej odpowiedzialności biznesu $w$ przedsiębiorstwach polskich na tle doświadczeń Wielkiej Brytanii i Niemiec, Wydawnictwo UE, Wrocław 2013.

[21] Ustawa z 27 sierpnia 2009 r. o finansach publicznych (Dz.U. nr 157, poz. 1240 ze zm.).

[22]Ustawa z dnia 21 listopada 2008 r. o pracownikach samorządowych (Dz.U. nr 223, poz. 1458 ze zm.).

[23]Van der Wal Z., de Graaf G., Lasthuizen K., What's Valued Most? Similarities and Differences between the Organizational Values of the Public and Private Sector, "Public Administration" 2008, 86(2).

[24]Zalewski A. (red.), Nowe zarządzanie publiczne $w$ polskim samorzadzie terytorialnym, Szkoła Główna Handlowa, Warszawa 2005.

\section{COHERENCE AND PECULIARITY OF THE VALUE OF THE PRIVATE}

\section{AND PUBLIC SECTOR}

The conducted research of the private and public performance allows to conclude that we may deal with gradual and progressive convergence of both sectors. More often public sector appeals to the market values and at the same time the private sector - to the code 
which is closer to the public one. It happens because of the growing social expectations towards both public and private organizations. Society expects that companies will conduct their business in consonance and respect with natural and social environment and participation in execution of social functions of the state. On the other hand society expects from public sector the decentralization of decisional centers, an inclusion of social groups into the public matters and moreover to be governed by the rules of effectiveness and coherence within the process of establishing and distributing of the welfare. The main target of the article has been to define common and diversified values of both - private and public sectors. More detailed targets of the article, whose role is to support the accomplishment of the main target, come as follows:

1) Defining the essence, types and meaning of the values,

2) Drawing up the profile of the main features and functions of the private and public sector,

3) Conducting the comparative analysis of the organizational values within the public and private sectors in the context of the evolution of management paradigm.

Keywords: values, New Public Management, Public governance, Good governance, Corporate Social Responsibility.

DOI:10.7862/rz.2017.hss.14

Przesłano do redakcji: styczeń 2017 r.

Przyjęto do druku: marzec 2017 r. 